\title{
Suicidal ideation in medical students: recent insights
}

\author{
Ricardo Coentre ${ }^{1,2}$ \\ Carlos Góis ${ }^{1,2}$ \\ 'Department of Psychiatry, Hospital \\ de Santa Maria, Centro Hospitalar \\ Lisboa Norte, EPE, Lisboa, Portugal; \\ ${ }^{2}$ Psychiatric University Clinic, Faculty \\ of Medicine, University of Lisbon, \\ Lisboa, Portugal
}

This article was published in the following Dove Press journal: Advances in Medical Education and Practice

Background: Previous studies have indicated that suicidal ideation is prevalent in medical students. The factors related to school admission processes and medical school environments contribute to this high prevalence. The consequences of suicidal ideation include suicide attempts and completed suicide. This article reviewed the recent literature on suicidal ideation in medical students.

Materials and methods: A systematic review of the literature was conducted to identify the articles published on the prevalence of suicidal ideation and associated factors in medical students. Original articles published from 2011 were included.

Results: Seventeen studies comprising a total of 13,244 medical students from 13 Western and non-Western countries were included. The prevalence of suicidal ideation ranged from $1.8 \%$ to $53.6 \%$. The most frequent factors associated with suicidal ideation in medical students were depression and depressive symptoms, a previous diagnosis of a psychiatric disorder, lower socioeconomic status/financial difficulties, having a history of drug use, and feeling neglected by parents. We did not find studies on interventional studies on suicidal ideation in medical students published in recent years.

Conclusion: We identified a number of non-Western studies published in recent years, overcoming the previous scarcity of research in this area. Findings confirmed that suicidal ideation in medical students remains a significant concern. Future studies should focus on preventive and treatment programs targeting the identified factors associated with suicidal ideation in medical students.

Keywords: suicidal ideation, medical students, depression, prevalence, suicide

\section{Introduction}

About 1 million people die from suicide every year, and in the past 45 years, the rate of suicide has increased by $60 \%$ worldwide. ${ }^{1}$ Suicide is the second leading cause of death among young people after car accident. ${ }^{1}$ Medical doctors are one of the highrisk groups for suicide. ${ }^{2,3}$ It seems that this problem arises during medical school., ${ }^{4,5}$ Medical students in their first year of studies have similar rates of psychological morbidity to the age-matched general population, but experience a worsening of their mental health as they progress through medical studies. ${ }^{6-8}$ In addition to depression, suicidal ideation is a strong predictor of attempted suicide. ${ }^{9}$ Suicidal ideation includes thinking about, considering, or planning suicide. ${ }^{10}$ The rates of suicidal ideation in medical students vary widely, ranging from $6.0 \%$ to $43.0 \% .^{4,11-13}$ In addition, female medical students have been found to have higher rates of suicidal ideation than male students. ${ }^{4}$ Medical students are vulnerable to suicidal ideation because of personal and
Correspondence: Ricardo Coentre Department of Psychiatry, Hospital de Santa Maria, Centro Hospitalar Lisboa Norte, EPE, Av. Professor Egas Moniz, 1649-035 Lisboa, Portugal

Tel +35I 2I 7805000

Email ricardomcoentre@gmail.com 
professional distress resulting from several factors. ${ }^{4}$ These include information overload, lack of leisure time, financial debt, being away from home, academic load, and work pressure. ${ }^{14}$ Also, contact with suffering, confronting with death, and caring for vulnerable persons could be other factors that trigger emotional problems in medical students. Some studies also showed that medical students experience depression, burnout, and mental disorders at higher rates than the general population, with deterioration over the medical course. ${ }^{12,15}$ Research has also reported that school admission processes led to the selection of individuals at risk of vulnerability to depressive disorders and suicidal ideation, namely the traits of perfectionism, obsession, neuroticism, and introversion, as well as low self-esteem. ${ }^{16,17}$ Negative consequences of poor mental health among medical students include poorer academic performance, substance use (including alcohol), dropout, and suicide. ${ }^{11,18,19}$ Despite their knowledge of the negative consequences, alcohol and drug use are quite high among medical students and do not differ significantly from other university students. ${ }^{20}$

Despite easy access to medical care, medical students are often reluctant to seek psychiatric help. ${ }^{21}$ Concerns about time, confidentiality, stigma, and the potential negative effects on their careers are associated with undertreatment of medical students for mental health problems. ${ }^{21,22}$ Identification of the prevalence and factors associated with suicidal ideation in medical students can help the timely detection and provision of appropriate interventions to reduce the magnitude of the problem. Furthermore, intervening at an early stage of medical training provides a way to help prevent later mental health problems, including the risk of suicide once students become practicing physicians.

This systematic review accumulated recent knowledge about suicidal ideation in medical students in both Western and non-Western countries.

\section{Materials and methods}

Our group conducted a systematic review of suicidal ideation in medical students including articles published up to June 2011.5 In the current systematic review, we provided an update to this research by including articles published between July 2011 and May 2018. PubMed and Cochrane databases were searched for published articles using the keywords "suicidal ideation," "suicidal behavior," and "medical students". In addition, we screened the reference lists of identified articles for any additional relevant studies. The articles surviving selection were downloaded, read in full, and evaluated for eligibility. The articles were included in the systematic review if they were original articles, written in English, and included a sample of medical students. We excluded the following studies from current review: 1) duplicate reports; 2) articles with insufficient data on the prevalence of suicidal ideation for analysis, meta-analysis, or reviews; 3 ) articles reporting a sample of mixed college students and where medical students were not analyzed as a specific group; and 4) articles published in languages other than English. In the case of multiple publications deriving from the same study sample, we selected the articles reporting the largest or the most recent data.

\section{Results \\ Article selection}

A total of 603 records were obtained from the PubMed and Cochrane database searches. A further four articles were identified through screening the references of these articles. After reading articles titles and abstracts, we selected 24 articles for further evaluation. Of these articles, seven articles were excluded after reading the full text. Finally, 17 studies were included in this systematic review. Figure 1 shows the selection of articles following PRISMA guidelines.

\section{Review of study characteristics}

Seventeen studies comprising an overall total of 13,244 medical students recruited in 13 different countries were included. ${ }^{9,23-38}$ The mean number of medical students included per study was 779, ranging from 114 to 4,402. All studies were cross-sectional in design. Suicidal ideation was assessed relating to the current time, over the past 12 months, during medical studies, and lifetime. The majority of studies measured suicidal ideation using specific questions. $^{23,24,26,28,29,31-34,36,37}$ The following scales were used to measure suicidal ideation in the previous studies: item 9 from the Beck Depression Inventory, ${ }^{25}$ Beck's Suicidal Ideation Scale (BSI), ${ }^{27}$ the Suicide Behaviors Questionnaire, ${ }^{30}$ item 9 of the Patient Health Questionnaire (PHQ), ${ }^{9}$ and item 6 of the Kutcher Adolescent Depression Scale. ${ }^{38}$ One study used questions about suicidal ideation as well as the General Health Questionnaire. ${ }^{35}$ Table 1 summarizes all the included studies, including country, year of training, number of students, instruments used to measure suicidal ideation, the prevalence of suicidal ideation, and other significant findings in each study.

\section{Prevalence of suicidal ideation}

The prevalence of suicidal ideation ranged from $1.8 \%$ to $53.6 \%$, reflecting some heterogeneity among the studies. In 

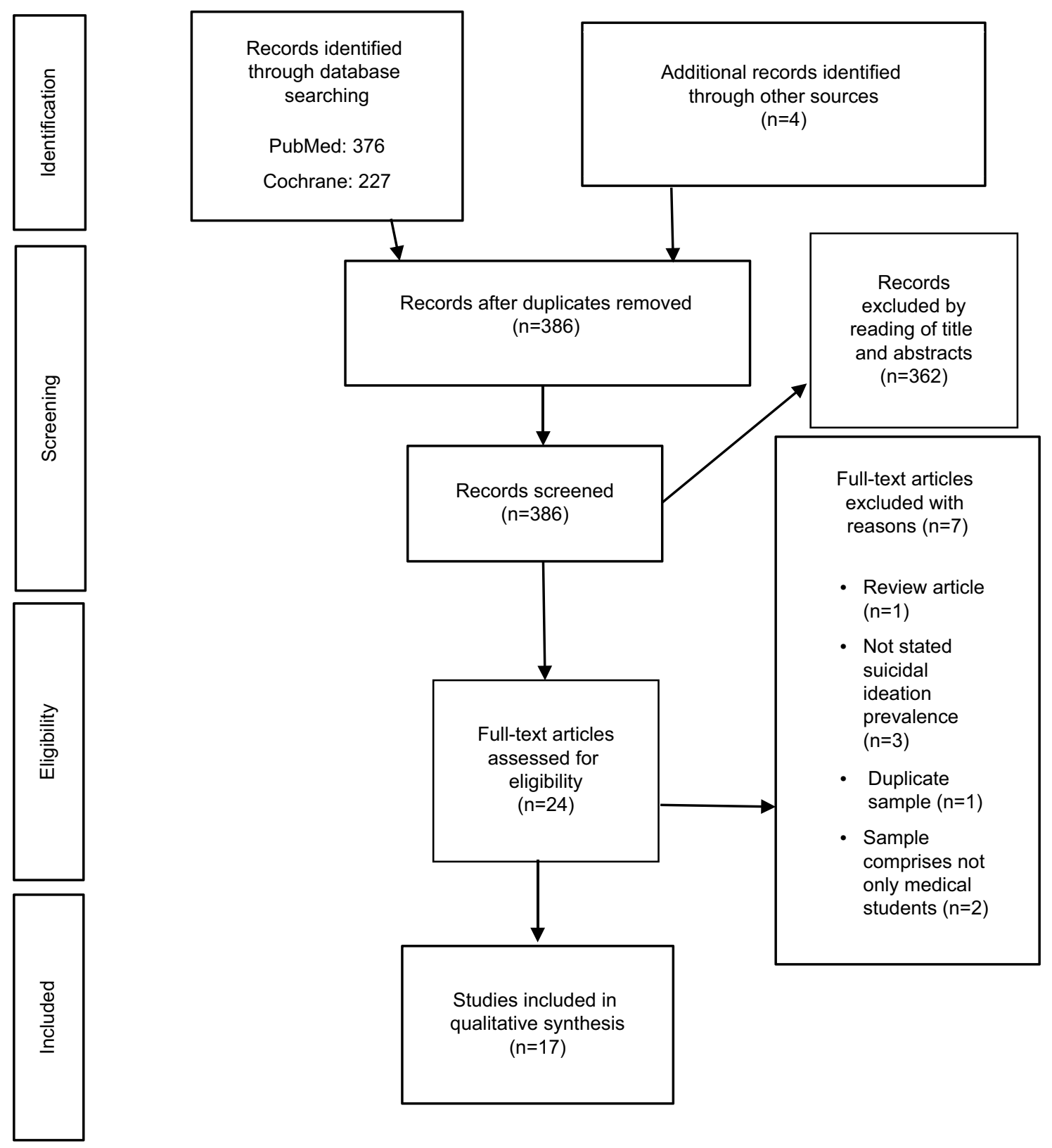

Figure I Flow chart of systematic identification of articles following PRISMA guidelines. Abbreviation: PRISMA, Preferred Reporting Items for Systematic reviews and Meta-Analysis.

consideration of prevalence according to timeframe, current suicidal ideation ranged from $1.8 \%$ to $24.6 \%$, during medical school time from $3.7 \%$ to $4.7 \%$, over the past 12 months from $7 \%$ to $35.6 \%$, and lifetime from $2.9 \%$ to $53.6 \%$. One study explicitly stated that the prevalence of suicidal ideation identified among medical students was higher than that for the age-matched general population. ${ }^{34}$

One study found a significantly higher prevalence of suicidal ideation in male students than female medical students, ${ }^{26}$ four studies found a significantly higher prevalence in female students than male students, ${ }^{27,29,36,37}$ and the remaining 12 studies did not find any statistically significant differences between the two genders. ${ }^{9}, 23-25,28,30-35,38$

Regarding the relationship between suicidal ideation and year of study, one study found that students in clinical years had a higher prevalence of suicidal ideation than those in preclinical years, ${ }^{23}$ two studies did not find any significant differences regarding year of study,,$^{25,34}$ and a further two studies found a higher prevalence of suicidal ideation in the first/pre-clinical years of medical studies..$^{27,35}$

The factors most frequently associated with suicidal ideation in medical students were depression and depressive 
Table I Characteristics of included studies

\begin{tabular}{|c|c|c|c|c|c|c|}
\hline Study & Country & $\begin{array}{l}\text { Year of } \\
\text { training }\end{array}$ & $\begin{array}{l}\text { Number } \\
\text { of } \\
\text { students }\end{array}$ & $\begin{array}{l}\text { Instrument } \\
\text { and cutoff } \\
\text { used }\end{array}$ & $\begin{array}{l}\text { Prevalence } \\
\text { of suicidal } \\
\text { ideation }\end{array}$ & Other significant findings \\
\hline $\begin{array}{l}\text { Adhikari } \\
\text { et al } \\
(20 \mid 7)^{23}\end{array}$ & Nepal & $\begin{array}{l}\text { First to } \\
\text { fourth }\end{array}$ & 343 & $\begin{array}{l}\text { Question } \\
\text { if they had } \\
\text { seriously } \\
\text { considered } \\
\text { committing } \\
\text { suicide while in } \\
\text { medical school }\end{array}$ & $4.7 \%$ & $\begin{array}{l}\text { No difference between females } \\
\text { and males. Clinical years and } \\
\text { depressed students with high } \\
\text { rates }\end{array}$ \\
\hline $\begin{array}{l}\text { Sun et al } \\
(2017)^{26}\end{array}$ & China & $\begin{array}{l}\text { First to } \\
\text { fifth }\end{array}$ & 2,198 & $\begin{array}{l}\text { Questions } \\
\text { about lifetime } \\
\text { suicidal } \\
\text { ideation, } \\
\text { I2-month } \\
\text { suicidal } \\
\text { ideation, } \\
\text { suicide plan, } \\
\text { and suicide } \\
\text { attempt }\end{array}$ & $\begin{array}{l}\text { Lifetime } \\
\text { suicidal } \\
\text { ideation: } 17.9 \% \\
\text { I2-month } \\
\text { suicidal } \\
\text { ideation:8.2\% }\end{array}$ & $\begin{array}{l}\text { Suicide plan: } 5.2 \% \\
\text { Suicide attempt: } 4.3 \% \\
\text { Male, mother's education, and } \\
\text { parenting style }\end{array}$ \\
\hline $\begin{array}{l}\text { Torres } \\
\text { et al } \\
(2017)^{25}\end{array}$ & Brazil & $\begin{array}{l}\text { First to } \\
\text { sixth }\end{array}$ & 475 & Item 9 of $\mathrm{BDI}$ & $\begin{array}{l}\text { Current } \\
\text { suicidal } \\
\text { ideation: } 7.2 \%\end{array}$ & $\begin{array}{l}\text { Living alone, thoughts of } \\
\text { abandoning the course, } \\
\text { moderate or severe depressive } \\
\text { symptoms, and probable } \\
\text { obsessive-compulsive disorder } \\
\text { associated with suicidal } \\
\text { ideation }\end{array}$ \\
\hline $\begin{array}{l}\text { Ahmed } \\
\text { et al } \\
(2016)^{27}\end{array}$ & Egypt & $\begin{array}{l}\text { First year, } \\
\text { pre-clinical } \\
\text { and clinical } \\
\text { years }\end{array}$ & 612 & BSI Scale & $\begin{array}{l}12.75 \% \\
(B S I>24)\end{array}$ & $\begin{array}{l}\text { Lifetime suicide plan: } 3.59 \% \\
48 \text { hours suicide plan: } 2.78 \%\end{array}$ \\
\hline $\begin{array}{l}\text { Coentre } \\
\text { et al } \\
(2016)^{28}\end{array}$ & Portugal & $\begin{array}{l}\text { Fourth } \\
\text { and fifth }\end{array}$ & 456 & $\begin{array}{l}3 \text { questions } \\
\text { about medical } \\
\text { school time } \\
\text { of suicidal } \\
\text { ideation, } \\
\text { suicide plan, } \\
\text { and suicide } \\
\text { attempt }\end{array}$ & $\begin{array}{l}\text { Medical } \\
\text { school suicidal } \\
\text { ideation: } 3.7 \%\end{array}$ & $\begin{array}{l}\text { Medical school suicide plan: } \\
\text { I. } 1 \% \\
\text { Medical school suicide attempt: } \\
0.7 \%\end{array}$ \\
\hline $\begin{array}{l}\text { Wege } \\
\text { et al } \\
(2016)^{36}\end{array}$ & Germany & First & 389 & $\begin{array}{l}\text { I question } \\
\text { about lifetime } \\
\text { suicidal } \\
\text { ideation }\end{array}$ & $\begin{array}{l}\text { Lifetime } \\
\text { suicidal } \\
\text { ideation: } 7.4 \%\end{array}$ & $\begin{array}{l}\text { Expected financial difficulties } \\
\text { associated with suicidal } \\
\text { ideation }\end{array}$ \\
\hline $\begin{array}{l}\text { Youssef } \\
\text { et al } \\
(2016)^{38}\end{array}$ & Pakistan & Second & 114 & KADS-6 & $\begin{array}{l}\text { Current } \\
\text { suicidal } \\
\text { ideation: } 24.6 \%\end{array}$ & $\begin{array}{l}\text { No statistically significant } \\
\text { difference between genders }\end{array}$ \\
\hline $\begin{array}{l}\text { MacLean } \\
\text { et al } \\
(2015)^{31}\end{array}$ & USA & $\begin{array}{l}\text { Not } \\
\text { specified }\end{array}$ & 385 & $\begin{array}{l}3 \text { questions } \\
\text { about suicidal } \\
\text { ideation (I2 } \\
\text { months and } \\
\text { lifetime) } \\
\text { and suicide } \\
\text { attempts }\end{array}$ & $\begin{array}{l}\text { Past } 12 \\
\text { months suicidal } \\
\text { ideation: } 11.7 \% \\
\text { Lifetime } \\
\text { suicidal } \\
\text { ideation: } 29.9 \%\end{array}$ & Lifetime suicide attempt: I.8\% \\
\hline $\begin{array}{l}\text { Dyrbye } \\
\text { et al } \\
(2014)^{32}\end{array}$ & USA & $\begin{array}{l}\text { First and } \\
\text { second }\end{array}$ & 4,402 & $\begin{array}{l}\text { I question } \\
\text { about past } 12 \\
\text { months suicidal } \\
\text { ideation }\end{array}$ & $\begin{array}{l}\text { Past } 12 \\
\text { months suicidal } \\
\text { ideation: } 9.4 \%\end{array}$ & $\begin{array}{l}\text { Medical students were } \\
\text { not more likely to have } \\
\text { experienced recent suicidal } \\
\text { ideation }\end{array}$ \\
\hline
\end{tabular}

(Continued) 
Table I (Continued)

\begin{tabular}{|c|c|c|c|c|c|c|}
\hline Study & Country & $\begin{array}{l}\text { Year of } \\
\text { training }\end{array}$ & $\begin{array}{l}\text { Number } \\
\text { of } \\
\text { students }\end{array}$ & $\begin{array}{l}\text { Instrument } \\
\text { and cutoff } \\
\text { used }\end{array}$ & $\begin{array}{l}\text { Prevalence } \\
\text { of suicidal } \\
\text { ideation }\end{array}$ & Other significant findings \\
\hline $\begin{array}{l}\text { Osama } \\
\text { et al } \\
(20 \mid 4)^{29}\end{array}$ & Pakistan & $\begin{array}{l}\text { First to } \\
\text { fifth }\end{array}$ & 331 & $\begin{array}{l}4 \text { questions } \\
\text { about suicidal } \\
\text { ideation }\end{array}$ & $\begin{array}{l}\text { Past I2 } \\
\text { months suicidal } \\
\text { ideation: } 35.6 \%\end{array}$ & $\begin{array}{l}\text { Lifetime suicide plan: I3.9\%; } \\
\text { Lifetime suicide attempt: } 4.8 \%\end{array}$ \\
\hline $\begin{array}{l}\text { Miletic } \\
\text { et al } \\
(20 \mid 4)^{30}\end{array}$ & Serbia & $\begin{array}{l}\text { First, } \\
\text { third, and } \\
\text { sixth }\end{array}$ & 1,296 & SBQ & $\begin{array}{l}\text { Lifetime } \\
\text { suicidal } \\
\text { ideation: } 2.9 \%\end{array}$ & $\begin{array}{l}\text { Lifetime suicide plan: } 0.5 \% \\
\text { Lifetime suicide attempt: } 0.6 \%\end{array}$ \\
\hline $\begin{array}{l}\text { Sobowale } \\
\text { et al } \\
(20 \mid 4)^{9}\end{array}$ & China & $\begin{array}{l}\text { Second } \\
\text { and third }\end{array}$ & 348 & $\begin{array}{l}\text { Item } 9 \text { of } \\
\text { PHQ-9 }\end{array}$ & $\begin{array}{l}\text { Current } \\
\text { suicidal } \\
\text { ideation: } 7.5 \%\end{array}$ & \\
\hline $\begin{array}{l}\text { Amiri } \\
\text { et al } \\
(20 / 2)^{24}\end{array}$ & $\begin{array}{l}\text { United } \\
\text { Arab } \\
\text { Emirates }\end{array}$ & $\begin{array}{l}\text { First to } \\
\text { sixth }\end{array}$ & 115 & $\begin{array}{l}\text { Questions } \\
\text { about suicidal } \\
\text { ideation and } \\
\text { suicide attempt } \\
\text { (lifetime, past } \\
12 \text { months, and } \\
\text { current) }\end{array}$ & $\begin{array}{l}\text { Lifetime } \\
\text { suicidal } \\
\text { ideation: } 17.5 \% \\
\text { Past I2 } \\
\text { months: } 7 \% \\
\text { Current: } 1.8 \%\end{array}$ & Lifetime suicide attempts: I.8\% \\
\hline $\begin{array}{l}\text { Fan et al } \\
(2012)^{33}\end{array}$ & $\begin{array}{l}\text { Taiwan- } \\
\text { China }\end{array}$ & $\begin{array}{l}\text { First and } \\
\text { second }\end{array}$ & 435 & $\begin{array}{l}\text { I question } \\
\text { about current } \\
\text { suicidal } \\
\text { ideation }\end{array}$ & $\begin{array}{l}\text { Current } \\
\text { suicidal } \\
\text { ideation: I I.5\% }\end{array}$ & $\begin{array}{l}\text { Suicidal ideation higher in } \\
\text { second year compared to } \\
\text { first year. Students of lower } \\
\text { socioeconomic status with } \\
\text { noninflammatory joint pain, } \\
\text { with headache, with sleep } \\
\text { disorders and depressed more } \\
\text { likely to have experienced } \\
\text { suicidal ideation }\end{array}$ \\
\hline $\begin{array}{l}\text { Goyal } \\
\text { et al } \\
(2012)^{37}\end{array}$ & India & $\begin{array}{l}\text { First } \\
\text { year to } \\
\text { internship }\end{array}$ & 265 & $\begin{array}{l}7 \text { questions } \\
\text { about lifetime } \\
\text { suicidal } \\
\text { ideation and } \\
\text { suicide attempt }\end{array}$ & $\begin{array}{l}\text { Lifetime } \\
\text { suicidal } \\
\text { ideation: } 53.6 \%\end{array}$ & $\begin{array}{l}\text { Lifetime suicide attempt: } 2.7 \% \\
\text { Suicidal ideation was higher } \\
\text { in first year, associated with } \\
\text { "impulsive or reckless behavior } \\
\text { in difficult situations", feeling } \\
\text { of being "better off dead" and } \\
\text { "it's all too much to manage" } \\
\text { Suicidal ideation higher among } \\
\text { females and nonworking } \\
\text { mothers }\end{array}$ \\
\hline $\begin{array}{l}\text { Menezes } \\
\text { et al } \\
(2012)^{10}\end{array}$ & Nepal & $\begin{array}{l}\text { Second } \\
\text { and third }\end{array}$ & 206 & $\begin{array}{l}4 \text { questions } \\
\text { about past } 12 \\
\text { months suicidal } \\
\text { ideation } \\
\text { included in the } \\
\text { GHQ-28 } \\
3 \text { questions } \\
\text { about lifetime } \\
\text { suicidal } \\
\text { ideation, } \\
\text { suicidal plan, } \\
\text { and suicidal } \\
\text { attempt }\end{array}$ & $\begin{array}{l}\text { Past I2 } \\
\text { months suicidal } \\
\text { ideation: } 10.7 \% \\
\text { Lifetime } \\
\text { suicidal } \\
\text { ideation: } 18.4 \%\end{array}$ & $\begin{array}{l}\text { Lifetime suicide plans: I\% } \\
\text { Lifetime suicide attempt: I\% } \\
\text { Factors associated with } \\
\text { suicidal ideation were primarily } \\
\text { dissatisfaction with academic } \\
\text { performance, being in the } \\
\text { clinical semesters, having } \\
\text { history of drug abuse, and } \\
\text { feeling neglected by parents }\end{array}$ \\
\hline $\begin{array}{l}\text { van } \\
\text { Niekerk } \\
\text { et al } \\
(2012)^{34}\end{array}$ & $\begin{array}{l}\text { South } \\
\text { Africa }\end{array}$ & $\begin{array}{l}\text { First to } \\
\text { fifth }\end{array}$ & 874 & $\begin{array}{l}\text { I question } \\
\text { about lifetime } \\
\text { suicidal } \\
\text { ideation }\end{array}$ & $\begin{array}{l}\text { Lifetime } \\
\text { suicidal } \\
\text { ideation: } 32.3 \%\end{array}$ & $\begin{array}{l}\text { Lifetime suicide attempt: } 6.2 \% \\
\text { Suicidal ideation three times } \\
\text { higher than the general age- } \\
\text { matched population } \\
\text { Suicidal ideation had a strong } \\
\text { association with suicide } \\
\text { attempt }\end{array}$ \\
\hline
\end{tabular}

Abbreviations: BDI, Beck Depression Inventory; BSI, Beck's Suicidal Ideation Scale; GHQ-28, General Health Questionnaire; KADS-6, Kutcher Adolescent Depression Scale; PHQ-9, item 9 of the Patient Health Questionnaire; SBQ, Suicide Behaviors Questionnaire. 
symptoms, ${ }^{9,23,25,33,34}$ previous diagnosis of a psychiatric disorder, ${ }^{29,34}$ lower socioeconomic status/financial difficulties, ${ }^{33,36}$ having a history of drug use, ${ }^{10,29}$ and feeling neglected by parents. ${ }^{10,29}$ Other factors associated with suicidal ideation included dissatisfaction with academic performance as a primary concern, ${ }^{10}$ a history of impulsive or reckless behavior in difficult situations, ${ }^{37}$ feeling of being better off dead, ${ }^{37}$ nonworking mothers, ${ }^{37}$ living alone,${ }^{25}$ thoughts of abandoning the course ${ }^{25}$ sleep disorders, ${ }^{33}$ previous suicidal attempts, ${ }^{34}$ mother's education level, ${ }^{26}$ and mother's parenting style. ${ }^{26}$

It is interesting to note that some studies reported similar levels of cannabis use in medical students compared to that in the general population, despite medical students having a better knowledge about the associated risks to both their own health status and that of their future patients. ${ }^{31}$

Few studies have been conducted on the protective factors of suicidal ideation in medical students. However, being married was identified as a factor associated with lower odds of suicidal ideation within the previous 12 months. ${ }^{32}$

\section{Discussion}

This systematic review included 17 studies about suicidal ideation in medical students published between July 2011 and May 2018. We found evidence that suicidal ideation in medical students presents a concern. Three studies were published in 2017, four in 2016, one in 2015, four in 2014, and five in 2012. Our previous systematic review consisted of 10 studies published between January 2005 and June 2011.5

Recently, an increase in the articles published outside US/ Canada and Europe was observed, with the current systematic review including three studies from Europe (Portugal, Germany, and Serbia), ${ }^{28,30,36}$ two from USA, ${ }^{31,32}$ nine from Asia (Nepal, United Arab Emirates, China, Pakistan, and India), ${ }^{9}$, 10,23,24,26,29,33,37,38 two from Africa (Egypt and South Africa), ${ }^{27,34}$ and one from South America (Brazil). ${ }^{25}$ In contrast, the overwhelming majority of studies published before 2011 were from USA, Canada, and Europe. Thus, suicidal ideation is a problem worldwide, independent of geographical location, for both Western and non-Western countries. The prevalence of suicidal ideation seems not to differ between countries from different continents or locations. Interestingly, we did not find any published articles from Australia or New Zealand.

The range in prevalence of suicidal ideation in medical students is quite large among studies. Two important factors contribute to this: the different instruments used to measure suicidal ideation and the different timeframes in which suicidal ideation was evaluated. The use of different instruments hampered comparisons of the prevalence of suicidal ideation among studies. This systematic review indicates that suicidal ideation is a relevant problem in medical students and probably higher than age-matched general population.

The results are inconsistent regarding the association between suicidal ideation and gender. This is similar to the pattern found in studies published before 2011. Recent findings show some trend toward indicating being female as a risk factor for suicidal ideation in medical students, as the majority of studies either did not find a statistically significant difference between genders or found that females are more prone to suicidal ideation.

Our results were also inconclusive regarding the year of study in medical school and prevalence of suicidal ideation. The results are almost equally divided in findings taking into account the year of study in medical school. Therefore, we cannot state whether suicidal ideation prevalence progressively increases with time spent in medical school.

As mentioned earlier, there is a paucity of published research on preventive and treatment interventions. We found only one recent intervention study for suicidality, and this was not in medical students but in paramedical students (and therefore excluded from the current review). ${ }^{39}$ Muriungi and Ndetei conducted a clinical trial across seven campuses in Kenya Medical Training College involving an experimental group $(n=1181)$ and a control group $(n=1926)$ to determine the effectiveness of psychoeducation on suicidality as well as other symptoms (depression, hopelessness, anxiety, and risk of substance abuse). Suicidal ideation was measured using Beck's Scale for Suicidal Ideation at baseline, 3 months, and 6 months. The experimental group was assigned to four psychoeducation sessions (totaling 16 hours), which included lectures, simulations, group discussions, and role-plays about the factors associated with suicidality and other symptoms relating to mental health. There were no interventions in the control group. Results revealed no statistically significant reduction in symptom severity between the experimental and control groups at 3 months, but there was a significant difference at 6 months follow-up. This study demonstrates that a simple and easy intervention like psychoeducation can be effective in reducing not only suicidal ideation but also depression, hopelessness, suicide plans, suicide attempts, anxiety, depression, and risk of substance abuse.

The current systematic review has several limitations. We only included articles published in English, and in doing so, we could have excluded other important researches. Also, we did not perform a meta-analysis because the use of different instruments and timeframes limited the application of this approach. 
Future studies should focus on the contribution of medical school culture in suicidal ideation, trying to identify which particular factor in medical education could contribute to suicidal ideation in medical students.

Also, future research should study interventions to reduce suicidal ideation experienced by medical students. Two of the factors found here to be associated with suicidal ideation were drug use and financial status, and interventions addressing these could be useful. Identifying depression and depressive symptoms, the most frequent factors associated with suicidal ideation in medical students, as well as the treatment for psychological distress, should be included in interventions. Preliminary data suggest that simple and general well-being interventions could have significant results in lowering rates of mental health problems, including suicidal ideation, in medical students. Also, we think self-care and self-reflecting in medical education, for example groups of reflecting students, could be a way of a preventive method for suicidal ideation and other psychological problems. Approaching ways of reducing the reluctance of help-seeking in medical students should be addressed, reducing de-stigmatization of mental health problems.

\section{Conclusion}

The articles published in recent years overcame the scarcity of published non-Western studies in previous years. Recent findings confirm that suicidal ideation is a significant problem for medical students. The major risk factors for medical students in terms of suicidal ideation included having depression or depressive symptoms, any other psychiatric diagnoses, feeling neglected by parents, having a history of drug use, low socioeconomic status, and/or financial difficulties. Future studies should focus on preventive as well as treatment programs to reduce suicidal ideation in medical students, and thus reducing suicidal attempts and completed suicides.

\section{Disclosure}

The authors report no conflicts of interest in this work.

\section{References}

1. World Health Organization. Preventing Suicide: A Global Imperative. Geneva: World Health Organization; 2014. Available from: http:// apps.who.int/iris/bitstream/10665/131056/1/9789241564779_eng. pdf?ua=1\&ua=1. Accessed July 18, 2018.

2. Shanafelt TD, Balch CM, Dyrbye L, et al. Special report: suicidal ideation among American surgeons. Arch Surg. 2011;146(1):54-62.

3. Schernhammer ES, Colditz GA. Suicide rates among physicians: a quantitative and gender assessment (meta-analysis). Am J Psychiatry. 2004;161(12):2295-2302.

4. Dyrbye LN, Thomas MR, Massie FS, et al. Burnout and suicidal ideation among U.S. medical students. Ann Intern Med. 2008;149(5):334-341.
5. Moutinho Coentre R, Luisa Figueira M. Depression and suicidal behavior in medical students: a systematic review. Curr Psychiatry Rev. 2015;11(2):86-101.

6. Carson AJ, Dias S, Johnston A, et al. Mental health in medical students. A case control study using the 60 item General Health Questionnaire. Scott Med J. 2000;45(4):115-116.

7. Rosal MC, Ockene IS, Ockene JK, Barrett SV, Ma Y, Hebert JR. A longitudinal study of students' depression at one medical school. Acad Med. 1997;72(6):542-546.

8. Yusoff MSB, Mat Pa MN, Esa AR, Abdul Rahim AF. Mental health of medical students before and during medical education: a prospective study. J Taibah Univ Med Sci. 2013;8(2):86-92.

9. Sobowale K, Zhou N, Fan J, Liu N, Sherer R. Depression and suicidal ideation in medical students in China: a call for wellness curricula. Int J Med Educ. 2014;5:31-36.

10. Menezes RG, Subba SH, Sathian B, et al. Suicidal ideation among students of a medical college in Western Nepal: a cross-sectional study. Leg Med. 2012;14(4):183-187.

11. Tyssen R, Vaglum P, Grønvold NT, Ekeberg O. Suicidal ideation among medical students and young physicians: a nationwide and prospective study of prevalence and predictors. J Affect Disord. 2001;64(1):69-79.

12. Goebert D, Thompson D, Takeshita J, et al. Depressive symptoms in medical students and residents: a multischool study. Acad Med. 2009;84(2):236-241.

13. Martinac M, Sakić M, Skobić H, Jakovljević M. Suicidal ideation and medical profession: from medical students to hospital physicians. Psychiatr Danub. 2003;15(3-4):185-188.

14. Yiu V. Supporting the well-being of medical students. CMAJ. 2005;172(7):889-890.

15. Dyrbye LN, Thomas MR, Power DV, et al. Burnout and serious thoughts of dropping out of medical school: a multi-institutional study. Acad Med. 2010;85(1):94-102.

16. Hirschfeld RM, Klerman GL. Personality attributes and affective disorders. Am J Psychiatry. 1979;136(1):67-70.

17. Humphris G, Kaney S. The encouragement of 'perfect' health professionals. Med Educ. 1998;32(5):452-455.

18. Midtgaard M, Ekeberg Ø, Vaglum P, Tyssen R. Mental health treatment needs for medical students: a national longitudinal study. Eur Psychiatry. 2008;23(7):505-511.

19. Mandal A, Ghosh A, Sengupta G, Bera T, Das N, Mukherjee S. Factors affecting the performance of undergraduate medical students: a perspective. Indian J Community Med. 2012;37(2):126-129.

20. Webb E, Ashton CH, Kelly P, Kamah F, Kamali F. An update on British medical students' lifestyles. Med Educ. 1998;32(3):325-331.

21. Tjia J, Givens JL, Shea JA. Factors associated with undertreatment of medical student depression. J Am Coll Heal. 2002;53(5):219-224.

22. Givens JL, Tjia J. Depressed medical students' use of mental health services and barriers to use. Acad Med. 2002;77(9):918-921.

23. Adhikari A, Dutta A, Sapkota S, Chapagain A, Aryal A, Pradhan A. Prevalence of poor mental health among medical students in Nepal: a cross-sectional study. BMC Med Educ. 2017;17(1):232.

24. Amiri L, Voracek M, Yousef S, et al. Suicidal behavior and attitudes among medical students in the United Arab Emirates. Crisis. 2013;34(2):116-123.

25. Torres AR, Campos LM, Lima MCP, Ramos-Cerqueira ATA. Suicidal ideation among medical students: prevalence and predictors. J Nerv Ment Dis. 2018;206:160-168.

26. Sun L, Zhou C, Xu L, Li S, Kong F, Chu J. Suicidal ideation, plans and attempts among medical college students in china: the effect of their parental characteristics. Psychiatry Res. 2017;247:139-143.

27. Ahmed SA, Omar QH, Abo Elamaim AA. Forensic analysis of suicidal ideation among medical students of Egypt: a crosssectional study. $J$ Forensic Leg Med. 2016;44:1-4.

28. Coentre R, Faravelli C, Figueira ML. Assessment of depression and suicidal behaviour among medical students in Portugal. Int J Med Educ. 2016;7:354-363. 
29. Osama M, Islam MY, Hussain SA, et al. Suicidal ideation among medical students of Pakistan: a cross-sectional study. J Forensic Leg Med. 2014;27:65-68.

30. Miletic V, Lukovic JA, Ratkovic N, Aleksic D, Grgurevic A. Demographic risk factors for suicide and depression among Serbian medical school students. Soc Psychiatry Psychiatr Epidemiol. 2015;50(4):633-638.

31. Maclean L, Booza J, Balon R. The impact of medical school on student mental health. Acad Psychiatry. 2016;40(1):89-91.

32. Dyrbye LN, West CP, Satele D. Burnout among U.S. medical students, residents, and early career physicians relative to the general U.S. population. Acad Med. 2014;89:443-451.

33. Fan AP, Kosik RO, Mandell GA, et al. Suicidal ideation in medical students: who is at risk? Ann Acad Med Singapore. 2012;41(9):377-382.

34. van Niekerk L, Scribante L, Raubenheimer PJ. Suicidal ideation and attempt among South African medical students. SAfr Med J. 2012;102(6 Pt 2):372.
35. Menezes RG, Subba SH, Sathian B, et al. Suicidal ideation among students of a medical college in Western Nepal: a cross-sectional study. Leg Med (Tokyo). 2012;14(4):183-187.

36. Wege N, Muth T, Li J, Angerer P. Mental health among currently enrolled medical students in Germany. Public Health. 2016;132:92-100.

37. Goyal A, Kishore J, Anand T, Rathi A. Suicidal ideation among medical students of Delhi. J Ment Heal Hum Behav. 2012;17(1):60-70.

38. Youssef M, Daud S, Shafique MM. Gender difference in depression and suicidal ideation of medical students. PJMHS. 2016;10(3):1053-1056.

39. Muriungi SK, Ndetei DM. Effectiveness of psycho-education on depression, hopelessness, suicidality, anxiety and substance use among basic diploma students at Kenya Medical Training College. South African Journal of Psychiatry. 2013;19(2):10.

\section{Publish your work in this journal}

Advances in Medical Education and Practice is an international, peerreviewed, open access journal that aims to present and publish research on Medical Education covering medical, dental, nursing and allied health care professional education. The journal covers undergraduate education, postgraduate training and continuing medical education including emerging trends and innovative models linking education, research, and health care services. The manuscript management system is completely online and includes a very quick and fair peer-review system. Visit http://www.dovepress.com/testimonials.php to read real quotes from published authors.

Submit your manuscript here: http://www.dovepress.com/advances-in-medical-education-and-practice-journal 